\title{
Hydrogeochemistry and groundwater quality assessment of the multilayered aquifer in lower Kelantan Basin, Kelantan, Malaysia
}

\begin{abstract}
ABSTRCT
Continual expansion of population density, urbanization, agriculture, and industry in most parts of the world has increased the generation of pollution, which contributes to the deterioration of surface water quality. This causes the dependence on groundwater sources for their daily needs to accumulate day by day, which raises concerns about their quality and hydrogeochemistry. This study was carried out to increase understanding of the geological setup and assess the groundwater hydrogeochemical characteristics of the multilayered aquifers in Lower Kelantan Basin. Based on lithological data correlation of exploration wells, the study area can be divided into three main aquifers: shallow, intermediate and deep aquifers. From these three aquifers, 101 groundwater samples were collected and analyzed for various parameters. The results showed that $\mathrm{pH}$ values in the shallow, intermediate and deep aquifers were generally acidic to slightly alkaline. The sequences of major cations and anions were $\mathrm{Na}^{+}>\mathrm{Ca}^{+}>\mathrm{Mg}^{+}>\mathrm{K}^{+}$and $\mathrm{HCO} 3->\mathrm{Cl}->\mathrm{SO} 42->\mathrm{CO} 32-$, respectively. In the intermediate aquifer, the influence of ancient seawater was the primary factor that contributed to the elevated values of electrical conductivity (EC), $\mathrm{Cl}-$ and total dissolved solids (TDS). The main facies in the shallow aquifer were $\mathrm{Ca}-\mathrm{HCO} 3$ and $\mathrm{Na}-\mathrm{HCO} 3$ water types. The water types were dominated by $\mathrm{Na}-\mathrm{Cl}$ and $\mathrm{Na}-\mathrm{HCO} 3$ in the intermediate aquifer and by $\mathrm{Na}-\mathrm{HCO} 3$ in the deep aquifer. The Gibbs diagram reveals that the majority of groundwater samples belonged to the deep aquifer and fell in the rock dominance zone. Shallow aquifer samples mostly fell in the rainfall zone, suggesting that this aquifer is affected by anthropogenic activities. In contrast, the results suggest that the deep aquifer is heavily influenced by natural processes.
\end{abstract}

Keyword: Hydrogeochemistry; Multilayered aquifer; Sequences of major ions; Hydrochemical facies; Seawater remnant. 